Tér és Társadalom 2. évf. 1988/1. 112-115. p.

RECENZIÓK

PAUL WHITE: THE WEST EUROPEAN CITY: A SOCIAL GEOGRAPHY

A nyugat-európai város: szociálgeográfia

(Longman, London and New York, 1985. 286 p.)

A szerzô a maga nemében egyedülálló felađatra vállalkozott. A korábbi hasonló próbálkozásokhoz képest idôben és térben is tágabb horizontú elemzést nyứjt a kötet. $\mathrm{A}$ bevezetô fejezetben rövid, de alapos áttekintést ad az európai városfejlődés történeti elốzményciról. A nyugateurópai városok történetủk során meglehetősen eltérô fejlődési pályákat futottak be, đe találhatók olyan közös vonások, melyek indokolttá teszik kiemelésüket a tipizálás során. FERNAND BRAUDEL tipizálását alapul véve, a szerzô a preindusztriális Európa három várostípusát különíti el: a feudális várost, a polgár várost és az abszolutista várost. A polgár vagy kereskeđô város elitje fóképp abban különbözik a feuđális város elitjétől, hogy hatalma elsősorban városi tevékenységekbôl ered, s nem a földbirtokból. Az abszolutista városra az jellemzô, hogy a gazdasági és politikai hatalom egy-egy családi dinasztia kezében összpontosul. A fentebbi típusok természetesen inkább csak ideáltípusként értelmezhetôk, hiszen a legtöbb város vegyes jellegú volt. Például Bécs a 12. századtól kettős arculatot tükrözött, kereskeđelmi központ és a feudális nemesség lakhelye egyszerre.

A 19. században a városok újabb típusa, az ipari város jelenik meg. E típusra konkrét példaként nemcsak az ilyenkor szokásos angol példákat idézi fel a szerző, hanem a német iparvárosokat is. Szemléletes képet nyújt az iparosodással együttjáró társađalmi átrétegzőđési folyamatról, és a szegregáció térbeli-települési jellemzóirôl.

A 20. századi városfejlódés új vonásaival foglalkozó fejezet különösen a ,városi szocializmus" sajátos városfejlesztô politikájáról nyújt érđekes információkat az olvasónak. Bécsben és Bolognában a helyi hatóságok a településfejlóđés egyre szélesebb körére gyakoroltak befolyást. A lakásépités támogatá- sától kezđve a slumosodási folyamat megállításáig, sôt a városközpontok tervszerú rehabilitálásáig terjed a helyhatósági, illetve az állami szabályozás köre. A településfejlesztés legsokrétübb eszközrenđszere Bécsben fejlöđött $\mathbf{k i}$, ugyanakkor a másik végletet a portugál vagy görög városok képviselik, ahol a piaci erốk még ma is meghatározó szerepet játszanak.

A lakásviszonyok elemzése során szembetủnő különbséget állapít meg a szerző a kontinentális Európa és Anglia között. NyugatEurópában sokkal nagyobb a szerepe a bérlakások különböző formáinak. Közép- és ÉszakEurópában a kormányzati szervek az elmúlt 70 év során meghatározó szerepet játszottak a lakásépítési programokban. Ugyanakkor Angliában a magántulajdonú lakás és az alacsonyabb beépitettségi fok a jellemző.

A nemzetközi és a belső migrációs folyamatok különösen a második világháborút követôen gyakoroltak jelentős hatást NyugatEurópa városfejlőđésére. A nemzetközi munkaerổmozgás egyes nagyvárosok etnikai összetételét alapvetỏen megváltoztatta. Ezek a változások a francia, az angol és a német nagyvárosok esetében komoly politikai feszültséget is teremtettek. Az érintett városokban az egyes városrészek funkciói is átalakultak, a lakóhelyi szegráció új formái alakultak ki. Sok városban az idegenek egyes termelő és szolgáltató ágazatokban döntô szerepet játszanak. Érdekes koncepciót fejt ki a szerző ezen városok đuális gazdasági struktúrájáról. $\mathrm{Az}$ idegenek beáramlása lehetővé tette a kevésbé gépesíthető, vagy nehezebb fizikai munkát igénylő szektorok zavartalan múködését a korábbinál alacsonyabb munkabérek mellett, ugyanakkor a hazai, képzettebb munkaerő gyorsabban átáramolhatott a mođern ágazatokba.

Részletes képet nyújt a kötet a belső, 
történelmi városrészek helyzetének változásáról. Az 1960-as és 70es évek összehangolt kormányzati és helyi közigazgatási intézkedései a slumosodási folyamatot a legtöbb helyen megállították. Sốt, az utóbbi néhány évben a belvárosi lakásárak gyors emelkedését figyelhetjưk meg. Még Angliában is - ahol a zöldövezeti lakás magas társadalmi presztízsének régi történelmi múltja van - a belvárosi lakásárak emelkednek a leggyorsabban. Vagyis a nyugateurópai városokban a belvárosnak, mint lakóhelynek a társadalmi presztízse egyértelmúen emelkedik.

A kötet tartalmi ismertetése és a pozitívumok kiemelése után szólnunk kell a hiányosságokról is. Ưgy érezzük, hogy nem mindig sikerült a szerzőnek a világgazdasági és a nemzeti szinten megjelenó azon gazdasági folyamatokat feltárni, amelyek a városfejlódés kereteit meghatározták. E hiányossággal függ össze, hogy az angol városfejlódésnek a kontinentális európaitól való eltérését a szerző valójában nem tudja megmagyarázni. A 19. század köze- pétól Angliának a világgazdaságban, Londonnak a bankvilágban és kereskedelemben betöltött szerepével magyarázható, hogy itt sajátos társadalmi rétegződés és értékrendszer teremtôdött meg. A ,városi" középosztály az 1850 es évektôl a vidéki családi házat tekinti „második”, sôt esetenként „első" otthonnak. Lancashire munkásarisztokráciája az 1850 es évektől vidéki vikendházak építésével járul hozzá a suburbanizáció erôsödéséhez. Vagyis a városfejlődést befolyásoló életmód és kulturális attitűdök a különböző társadalmi rétegek történelmi fejlődésmenetének hatására, illetve a rétegek egymásra hatása során termelổnek ki.

Osszegezve: a szerző átfogó képet nyújt az olvasónak a városfejlổdés történeti szakaszairól, s fơképpen a jelen idószak fó tendenciáiról. A kötetet részletes bibliográfia egészíti ki, magába foglalva nemcsak a humán geográfia, hanem a történeti és szociológiai irodalmat is.

TIMÁR LAJOS

\section{SZLOVAR GEOGRAFICSESZKIH NAZVANYIJ ZARUBEZSNIH SZTRAN}

(A külföld országai földrajzi neveinek szótára. Izd-vo „Nyedra”, Moszkva, 1986. 459 p.)

Az utóbbi évtizedek felgyorsult nemzetközi kapcsolatai (gazdasági, politikai, kulturális stb.) révén egyre több földrajzi név kerül a sajtó, a tudományos publikációk, a fordítások nyelvébe, a különféle államközi szerződések, megállapodások, együttmúköđési tervek és dokumentumok szövegeibe.

Magyar-orosz relációban ez - a két irásrendszer (és fonémarendszer) közt meglévő objektív és törvényszerü eltérések miatt - egy sor olyan problémát vet fel, amelyeknek az akut mivolta a nem nyelvész számára is érdekes lehet több vonatkozásban.

Nemrég jutott el Magyarországra $A$ külföld országai földrajzi neveinek szótára 3 . kiadása, amely kb. 40000 földrajzi nevet (településnevek, hegységek, folyók, patakok, csatornák stb. nevei) tartalmaz ábécérendben. A szótár a kartográfia, a földrajztudomány, a publicisztika szakemberei számára készült elsósorban, de a kiadók és más szervezetek it- letékeseinek éppúgy hasznos információkkal szolgál jó néhány vonatkozásban, mint az oroszul tudó átlagembernek (pl. az orosz transzkripció-transzliteráció, a hangsúly, az egyes idegen elemek fordíthatósága vonatkozásában).

Az oroszul jól tudó (illetve publikáló) hazai szakemberek számára is néha problémát jelent egy-két magyar földrajzi név (toponimia), illetve személynév (antroponimia) cirill betús átírása, jóllehet orosz részrôl a magyarorosz átírási rendszer - többé-kevésbé megnyugtató módon - már közel két évtizeddel ezelő́tt kidolgozásra és publikálásra került, több ízben is (vö.: R. SZ. GILJAREVSZKIJ B. A. SZTAROSZTYIN. Inosztrannije imena i nazvanyija $\mathbf{v}$ russzkom tyeksztye. M., 1969, 1978, 1985.). Szakmai berkekben ismeretes az a vita is, ami az érintett kérdésben folyt HADAS FERENC (RLTE) és A.V. SZUPERANSZKAJA (Moszkva) között a Russzkij 